\title{
Article \\ Obtaining Biocompatible Porous Composite Material Based on Zinc-Modified Hydroxyapatite and Lactide-Glycolide Copolymer
}

\author{
Daria Lytkina (D, Anastasiya Gutsalova, Dmitry Fedorishin and Irina Kurzina *D \\ Faculty of Chemistry, Tomsk State University, 634050 Tomsk, Russia; darya-lytkina@yandex.ru (D.L.); \\ nastya_w@bk.ru (A.G.); strix187@yandex.ru (D.F.) \\ * Correspondence: kurzina99@mail.ru; Tel.: +7-913-882-1028
}

check for

updates

Citation: Lytkina, D.; Gutsalova, A.; Fedorishin, D.; Kurzina, I. Obtaining Biocompatible Porous Composite Material Based on Zinc-Modified Hydroxyapatite and LactideGlycolide Copolymer. Crystals 2021, 11, 1519. https://doi.org/10.3390/ cryst11121519

Academic Editors: Nicolas Lebon and Laurent Tapie

Received: 4 October 2021

Accepted: 2 December 2021

Published: 5 December 2021

Publisher's Note: MDPI stays neutral with regard to jurisdictional claims in published maps and institutional affiliations.

Copyright: (c) 2021 by the authors. Licensee MDPI, Basel, Switzerland. This article is an open access article distributed under the terms and conditions of the Creative Commons Attribution (CC BY) license (https:// creativecommons.org/licenses/by/ $4.0 /)$

\begin{abstract}
The development of surgery in the field of bone tissue reconstruction provides a stable demand for new materials for implants. Of particular interest are materials based on hydroxyapatite, which are close in chemical composition to the elemental composition and structure of bone and have similar biologically active properties. In this work, the regularities of the formation of new composite materials based on a zinc-modified hydroxyapatite framework coated with a copolymer of lactide and glycolide were revealed for the first time. The aim of this work was to obtain porous composite materials based on zinc-modified hydroxyapatite and a copolymer of lactide and glycolide with properties suitable for use as a material for bone implants. The phase and elemental composition of the composites was studied by infrared spectroscopy, X-ray diffraction, and X-ray spectral microanalysis. Regularities have been established between the surface properties and the composition of materials, as well as their biocompatibility, determined using monocytes isolated from human peripheral blood. The antibacterial activity of the materials against gram-positive and gram-negative bacteria was determined.
\end{abstract}

Keywords: hydroxyapatite; lactide-glycolide copolymer; biocompatible material; bone replacement

\section{Introduction}

Currently, the field of chemical materials science is actively developing, aimed at creating new multifunctional materials designed to improve the quality and life expectancy of the population. Such materials are widely used, mainly in various branches of medicine. The development of new materials for bone implants requires knowledge of the chemical, physical, and mechanical properties of natural bone tissue, the qualitative and quantitative characteristics of which should be relied upon when creating implant materials. Recently, scientists have been faced with the task of obtaining materials that are closest in their structure and functional properties to the properties of natural bone tissue.

Bone tissue refers to connective tissue and has a complex structure and chemical composition. According to its chemical composition, bone is a composite material, consisting mainly of mineral and polymer components: calcium phosphates ( $70 \mathrm{wt} . \%)$, collagen $(\sim 22 \mathrm{wt} . \%)$, and water ( 8 wt.\%) [1,2]. Bone hardness and rigidity are provided by calcium phosphates in the form of crystalline hydroxyapatite (HA) whose general formula is $\mathrm{Ca}_{10}\left(\mathrm{PO}_{4}\right)_{6}(\mathrm{OH})_{2}$ and amorphous calcium phosphate $\left(\mathrm{Ca}_{\mathrm{x}}\left(\mathrm{PO}_{4}\right)_{\mathrm{y}} \cdot \mathrm{zH}_{2} \mathrm{O}\right)$. Hydroxyapatite crystals are needles up to $60 \mathrm{~nm}$ long, about $20 \mathrm{~nm}$ wide and up to $5 \mathrm{~nm}$ thick. In bone tissue, hydroxyapatite contains impurities of $\mathrm{Zn}^{2+}, \mathrm{Mg}^{2+}, \mathrm{Na}^{+}, \mathrm{CO}_{3}{ }^{2-}$ etc. [3].

The inorganic composition of bone tissue can be approximately expressed by the formula $\mathrm{Ca}_{10-\mathrm{x}} \mathrm{M}_{\mathrm{x}}\left(\mathrm{PO}_{4}\right)_{6-\mathrm{y}}\left(\mathrm{HPO}_{4}\right)_{\mathrm{y}}(\mathrm{OH})_{2}$ where $\mathrm{M}$ can be a metal cation replacing calcium at the $\mathrm{Ca} 1$ and $\mathrm{Ca} 2$ positions and $x$ characterizes the number of moles of the ion replacing calcium and can be in the range $0 \leq x \geq 10$. $y$ characterizes the amount of moles of hydrogen phosphate, which can be contained in amorphous HA along with phosphate ions [4]. In the crystal structure of apatite, calcium cations partially substitute other ions, for example, by $\mathrm{Ca}^{2+}, \mathrm{Pb}^{2+}, \mathrm{Cd}^{2+}, \mathrm{Sr}^{2+}, \mathrm{Ni}^{2+}, \mathrm{Eu}^{3+}, \mathrm{Al}^{3+}, \mathrm{Y}^{3+}, \mathrm{La}^{3+}, \mathrm{Ce}^{3+}, \mathrm{Na}^{+}, \mathrm{K}^{+}$etc. Cationic and anionic 
substitutions have a huge impact on the biological behavior of hydroxyapatite [5]. The crystal structure of HA allows various elements to replace others, and certain atoms are able to occupy completely or only partially different positions in the structure of HA, as a result of which a variety of compositions of natural phosphates with an apatite structure appear [6].

Due to their high biocompatibility and osteoconductivity, HA materials easily adsorb proteins, amino acids, and other substances, which, in turn, promote the adsorption and colonization of bacteria [7], which leads to material contamination. The most common organisms causing infections in implants are Staphylococcus aureus and Escherichia coli [8]. Usually, antibiotics or surgery are used to treat the infection. Removal of the implant and reoperation can lead to complications in the human body [9]. Recently, various organic [10] and inorganic [11] components with bactericidal properties have been added more and more often to prevent bacterial growth on the surface of HA. One of these components is zinc in the form of ions. $\mathrm{Zn}^{2+}$ ions have bactericidal, bacteriostatic, antiviral, and antiseptic effects against more than 500 pathogenic microorganisms and viruses. Their antimicrobial effect is stronger than that of penicillin, biomycin, and other antibiotics due to the inhibitory effect on bacterial strains that are resistant to antibiotics [5].

In comparison with ions of other metals with similar properties, zinc is relatively harmless [12]. Only exposure to high doses has a toxic effect, which makes acute zinc intoxication a rare occurrence. According to the Toxnet database of the US National Library of Medicine, the oral $\mathrm{LD}_{50}$ (lethal dose) for zinc is close to $3 \mathrm{~g} / \mathrm{kg}$ body weight, more than 10 times that of cadmium and 50 times that of mercury [12]. The human body contains up to $3 \mathrm{~g}$ of zinc, almost $90 \%$ of which is found in muscles and bones [13]. Excess zinc in the body causes hypocuremia, impaired iron mobilization, anemia, leukopenia, neutropenia, increased cholesterol levels, and impaired cardiac function [14-16]. While some other metals are well-known carcinogens, zinc is generally not considered as a cancer agent [17]. Adequate availability of zinc is of particular importance to the immune system. It plays a key role in many-sided cellular and molecular mechanisms [18,19]. Zinc influences the response of lymphocytes to mitogens and cytokines, serves as a cofactor for the thymus hormone thymulin, and is involved in signaling leukocytes [20-22]. The exact role of zinc in the regulation of apoptosis is controversial. Various studies show that, depending on its concentration, zinc can be pro- or anti-apoptosis, and both deprivation and excess zinc can induce apoptosis in the same cell line [23-25]. Further in our studies, we will show that an increase in the amount of open surface of hydroxyapatite with zinc leads to the death of macrophages, while in composite materials it will contribute to the viability of cell culture.

Substitution of $\mathrm{Ca}^{2+}$ for $\mathrm{Zn}^{2+}$ in hydroxyapatite increases the adhesion, proliferation, and differentiation of osteoblasts, and also stimulates osteogenic activity, growth, and bone healing. The overwhelming majority of studies of zinc-substituted HA indicate the zinc content in the concentration range of $0.1-4$ at.\%, which does not have a toxic effect on the body [26]. However, despite the fact that hydroxyapatite ceramics are biocompatible, their main disadvantage is fragility.

The desire to improve the mechanical calcium-phosphate ceramics has led to the creation of composite materials (CM) based on calcium phosphates and various polymers. One of these polymers is the lactide-glycolide copolymer (PLGA), which plays the role of a matrix and can be safely degraded in the human body and excreted naturally. In addition, PLGA has a controlled rate of biodegradation, which in turn makes it possible to influence the dynamics of composite resorption. HA in the PLGA matrix takes an active part in bone regeneration, acting as a substrate for the growth of new bone tissue. The purpose of this study was to obtain and establish the effect of the composition and structure of composite materials based on zinc-modified hydroxyapatite and a copolymer of lactide and glycolide on the physicochemical, surface, and biological properties. 


\section{Materials and Methods}

The synthesis of $\mathrm{Zn}_{\mathrm{x}} \mathrm{HA}$ powders was carried out according to the method described in [27], with the following scheme for obtaining samples:

$$
(10-x) \mathrm{Ca}\left(\mathrm{NO}_{3}\right)_{2}+6\left(\mathrm{NH}_{4}\right)_{2} \mathrm{HPO}_{4}+\mathrm{xZn}\left(\mathrm{NO}_{3}\right)_{2}+8 \mathrm{NH}_{4} \mathrm{OH} \rightarrow \mathrm{Ca}_{10-x} \mathrm{Zn}_{\mathrm{x}}\left(\mathrm{PO}_{4}\right)_{6}(\mathrm{OH})_{2}+6 \mathrm{H}_{2} \mathrm{O}+20 \mathrm{NH}_{4} \mathrm{NO}_{3}
$$

In the synthesis of the copolymer, the monomers L-lactide and glycolide were used. The lactide-glycolide copolymer was prepared by ionic ring-opening polymerization from L-lactide and glycolide [28]. The initial ratio of lactide-glycolide monomers was 75 percent of lactide and 25 percent of glycolide. The polymerization was carried out in a monomer melt in the presence of tin octanoate. Monomers are introduced simultaneously, the arrangement of monomer units in the chain is random. The final ratio of monomers in the copolymer, obtained by NMR, was $71.4 \%$ and $29.6 \%$, respectively. Gel permeation chromatography was used to determine the molecular weight of PLGA on Agilent System 1100 GPC equipped with an Agilent 1100 UV-Detektor (230 nm) DAD using a series of PSS SDV polymer columns with pore sizes from 50 to $105 \AA$. Tetrahydrofuran was used as an eluent. The number average molecular weight was $M_{n}=5 \times 10^{3}(\mathrm{~g} / \mathrm{mol})$, the weight-average molecular weight was $\mathrm{M}_{\mathrm{W}}=1.9 \times 10^{4}(\mathrm{~g} / \mathrm{mol})$, and polydispersity was $\mathrm{D}=3.75$.

The composites were obtained in several stages, according to [29]. The first stage was the production of tablets from $\mathrm{Zn}_{\mathrm{x}} \mathrm{HA}$ and a pore-forming agent by pressing. Sodium chloride was used as a pore-forming agent, which was taken in $25 \mathrm{wt}$ \%. Zinc-modified hydroxyapatite with sodium chloride was ground until a homogeneous mixture was formed, weighed portions of $\mathrm{m}=0.2 \mathrm{~g}$ were made, and tablets were pressed $(\mathrm{P}=200 \mathrm{~atm})$. Next, the tablets were calcined in a muffle furnace at a temperature of $700{ }^{\circ} \mathrm{C}$ for three hours. Different contents of $\mathrm{Zn} \mathrm{n}_{\mathrm{x}} \mathrm{HA}$ are required to obtain composites with different antibacterial properties. The second stage was to obtain a porous framework for the composite. The tablets were soaked in distilled water for three days with water renewal every $12 \mathrm{~h}$. Then, the porous zinc-modified hydroxyapatite was dried in air and then under vacuum. As a result, a line of substrates with different zinc content $(x=0.1$ and $0.5 \mathrm{~mol})$ were obtained. The third stage is the impregnation of the substrates with the polymer. For this, PLGA was dissolved in chloroform (concentration $0.1 \mathrm{~g} / \mathrm{mL}$ ). The tablets were immersed in the resulting solution and sonicated for $20 \mathrm{~min}$. Sonication is necessary to remove air bubbles from the substrate in order to obtain uniform coatings. For comparison, a control sample of a composite made of pure HA without additives was also obtained.

The content of the polymer component in the composites was determined by the gravimetric method (the weight of the impregnated tablets was compared with the weight of the initial porous substrates of the same area). Measurements were carried out on at least 5 samples. As a result, the ratio of the components in the final products was $7 \mathrm{wt} . \%$ [29].

The IR spectra of the composite materials were recorded on an Agilent Cary 630 FTIR spectrometer, IR spectra were recorded from powders using the disturbed total internal reflection. The surface morphology of the samples was investigated on a Hitachi TM-3000 scanning electron microscope with a magnification of 1000-5000 times at an accelerating voltage of $15 \mathrm{kV}$. Elemental analysis of the samples was carried out on a Quantax-70 attachment for energy dispersive microanalysis. Sample tablet was used that did not undergo any additional processing for SEM and EDS. The specific surface areas for composite materials based on HA and PLGA were estimated according to the data obtained on an automated 3Flex sorption unit manufactured by Micromeritics (USA). Before the experiment, all samples were degassed in vacuum $\left(10^{-2}\right.$ Top) at $80{ }^{\circ} \mathrm{C}$ for $2 \mathrm{~h}$. The degradation time of the material was determined by measuring the weight loss of the material after its incubation in sodium phosphate buffer with $\mathrm{pH}=7.4$ and drying to constant weight. The determination of the solubility of the samples was carried out by the method of complexometric titration of $\mathrm{Ca}^{2+}$ ions after holding. The volume of the pore space of the materials was determined by the method of hydrostatic weighing. The effect of composites on the num- 
ber of gram-negative and gram-positive bacteria (Escherichia coli, strain ATCC 25922) and (Staphylococcus aureus) during their cultivation in a liquid nutrient medium was determined by the Koch method in the author's modification [10]. To determine the assessment of the effect of materials on the viability of cells of the immune system, a cytotoxicity test with an Alamar Blue indicator was used. The signal intensity was measured using a Tecan Infinite 200 microreader at a wavelength of $540 \mathrm{~nm}$.

\section{Results and Discussion}

\subsection{Experimental Results and Discussion}

XRD results indicate the presence of the HA phase (Figure 1). According to XRD data, the samples can be considered as apatite of the hexagonal system. The shape of the diffraction patterns of the samples under study indicates a high degree of their crystallinity. Foreign phase peaks $\left(\mathrm{CaCO}_{3}, \mathrm{CaO}\right.$ and $\left.\mathrm{Ca}_{3}\left(\mathrm{PO}_{4}\right)_{2}\right)$ are absent, which indicates the formation of stoichiometric HA during the synthesis. The unit cell parameters of all samples, reported in Table 1, are in satisfactory agreement with the data of the International Center for Diffraction Standards (9-432). In the manufacture of the composite, sodium chloride (pore-forming agent) is used, which is registered as a separate phase. With an increase in the amount of the $\mathrm{Zn}$ substituent from 0.1 to $0.5 \mathrm{~mol}$ in the HA structure, the average crystallite size decreases from 68 to $60 \mathrm{~nm}$, while the average crystallite size of stoichiometric HA was $\sim 57 \mathrm{~nm}$ (Table 1$)$.

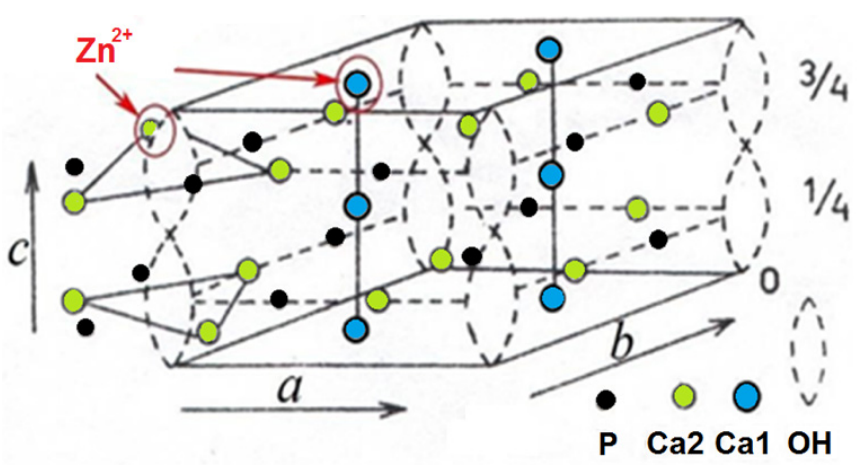

Figure 1. The structure of hydroxyapatite and possible localization of the incorporation of zinc into the crystal lattice.

Table 1. Parameters, unit cell volume, and coherent scattering region of $\mathrm{Zn}_{\mathrm{x}} \mathrm{HA}$ samples according to XRD data.

\begin{tabular}{cccccc}
\hline \multirow{2}{*}{ Sample } & \multicolumn{5}{c}{ Crystal Lattice Parameters } \\
\cline { 2 - 5 } & $\boldsymbol{a}, \AA$ & $\boldsymbol{b}, \AA$ & $\boldsymbol{c}, \AA$ & $\mathbf{\mathbf { A }}, \AA^{\mathbf{3}}$ & $\mathbf{C S R}, \mathbf{n m}$ \\
\hline $\mathrm{HA}$ & 9.435 & 9.435 & 6.887 & 530 & 57 \\
$\mathrm{Zn} \mathrm{x}_{\mathrm{H}} \mathrm{HA}(\mathrm{x}=0.1)$ & 9.435 & 9.438 & 6.856 & 529 & 68 \\
$\mathrm{Zn}_{\mathrm{x}} \mathrm{HA}(\mathrm{x}=0.5)$ & 9.425 & 9.435 & 6.851 & 527 & 60 \\
\hline
\end{tabular}

On the powder-XRD patterns of HA samples, there is a slight shift in the diffraction maxima and a decrease in their intensity with an increase in the amount of zinc (Figure 2). This is probably due to the incorporation of a "foreign" substituent ion into the HA crystal lattice with dimensions different from the ionic radius of calcium.

Table 1 shows the lattice parameters on the amount of introduced substituent for $\mathrm{Zn}_{\mathrm{x}} \mathrm{HA}$ samples. It can be seen that the incorporation of zinc into the structure of $\mathrm{HA}$ and an increase in its amount to $0.5 \mathrm{~mol}$ leads to a slight decrease in the unit cell parameters: from 9.435 to $9.425 \AA$, parameter a, and from 6.887 to $6.851 \AA$, parameter c. This may be due to the smaller radii of the substituent ion $\mathrm{Zn}^{2+}$ compared to the radius $\mathrm{Ca}^{2+}$. Likely the crystal lattice parameters decrease because there is a replacement of the calcium ion with a radius of $r_{i}=0.99 \AA$ for zinc with an ionic radius of $r_{i}=0.74 \AA$ (on the Polling scale [30]). 
The experimentally observed change in the parameters can be associated with the size of the modifying zinc ion and with the nature of the incorporation of ions into the lattice with the formation of solid solutions, which is confirmed by the shift of the reflections on the $X$-ray diffraction pattern to the region of smaller angles. In this case, the hexagonal system of the crystal lattice of the samples under study is retained. A decrease in the parameters of the crystal lattice in all directions leads to a natural decrease in the volume of the unit cell. Some studies [31] also note that the nature of the incorporation of zinc into the crystal lattice of hydroxyapatite is associated with a smaller radius of the zinc ion in comparison with calcium.

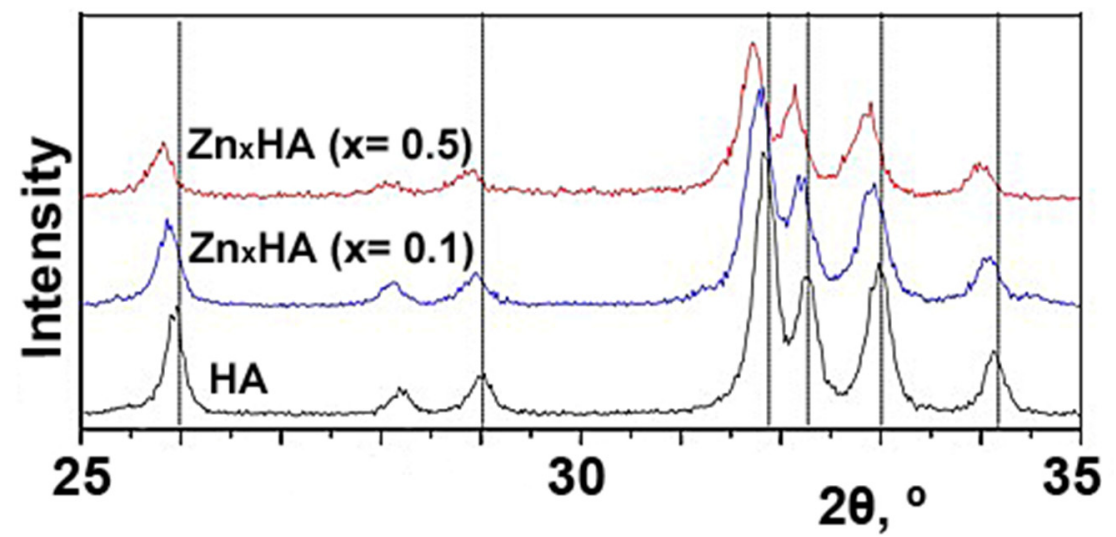

Figure 2. The diffractograms stoichiometric $\mathrm{HA}, \mathrm{Zn} \mathrm{n}_{\mathrm{x}} \mathrm{HA}(\mathrm{x}=0.1 ; 0.5)$ at intervals $2 \theta: 25-35^{\circ}$.

Analysis of the obtained composites by IR spectroscopy showed that the spectra (Figure 3b,c) exhibit bands characteristic of both HA and PLGA. The IR spectra of the composites contain bands corresponding to stretching vibrations of bonds in the PLGA structure, as well as bending vibrations of bonds of phosphate groups of $\mathrm{PO}_{4}{ }^{3-}$ included in the structure of HA. In the infrared spectra of the obtained samples of HA modified with zinc, all bands that are characteristic of HA are present (Figure 3a). The doublet in the range of $560-600 \mathrm{~cm}^{-1}$ corresponds to the deformation vibrations of the phosphate group, and the triplet $970-1060 \mathrm{~cm}^{-1}$ corresponds to the stretching vibrations of the phosphate groups [32]. Due to the fact that the mass fraction of the copolymer is small, the intensity of the $v_{\mathrm{CH}}, v_{\mathrm{CH} 3}$ and $v_{\mathrm{C}}=\mathrm{o}\left(1750 \mathrm{~cm}^{-1}\right)$ bands is extremely low.

\subsection{Investigation of Physical and Chemical Properties}

The results of studying the surface morphology by the SEM method (Figure 4a,b) showed that the composites are agglomerates of elongated particles characteristic of HA. The average particle size for $\mathrm{Zn}_{\mathrm{x}} \mathrm{HA}-\mathrm{PLGA}(\mathrm{x}=0.1)$ was $1.2 \pm 0.1 \mu \mathrm{m}$, and for $\mathrm{Zn}_{\mathrm{x}} \mathrm{HA}$ PLGA $(x=0.5)$ it was $0.9 \pm 0.1 \mu \mathrm{m}$. The reduction in particle size may be related to the amount of zinc ion concentration introduced. The open porosity for the composites and the original non-impregnated ceramics was calculated, which was $16.6 \% \mathrm{Zn}$ HA-PLGA $(\mathrm{x}=0.1), 14.3 \% \mathrm{Zn}_{\mathrm{x}} \mathrm{HA}-\mathrm{PLGA}(\mathrm{x}=0.5)$, and $26.2 \%$ for the ceramic framework, respectively. After impregnation, there is a decrease in open porosity in the material due to the filling of a part of the PLGA pores.

The relative content of calcium in relation to phosphorus is usually taken as a regulator to maintain mineral homeostasis and bone metabolism [33]. It has been suggested that variations in $\mathrm{Ca} / \mathrm{P}$ ratio are more important in assessing bone health than variations in $\mathrm{Ca}$ or $\mathrm{P}$ concentration. The elemental composition of the synthesized $\mathrm{Zn} \mathrm{n}_{\mathrm{x}} \mathrm{HA}$ powders according to the results of $X$-ray diffraction analysis (Table 2) shows that the atomic ratio of elements $(\mathrm{Ca}+\mathrm{Zn}) / \mathrm{P}$ is 1.7-1.8, which corresponds to the ratio of $\mathrm{Ca} / \mathrm{P}$ elements for bone tissue (1.4-2.0) [34]. 


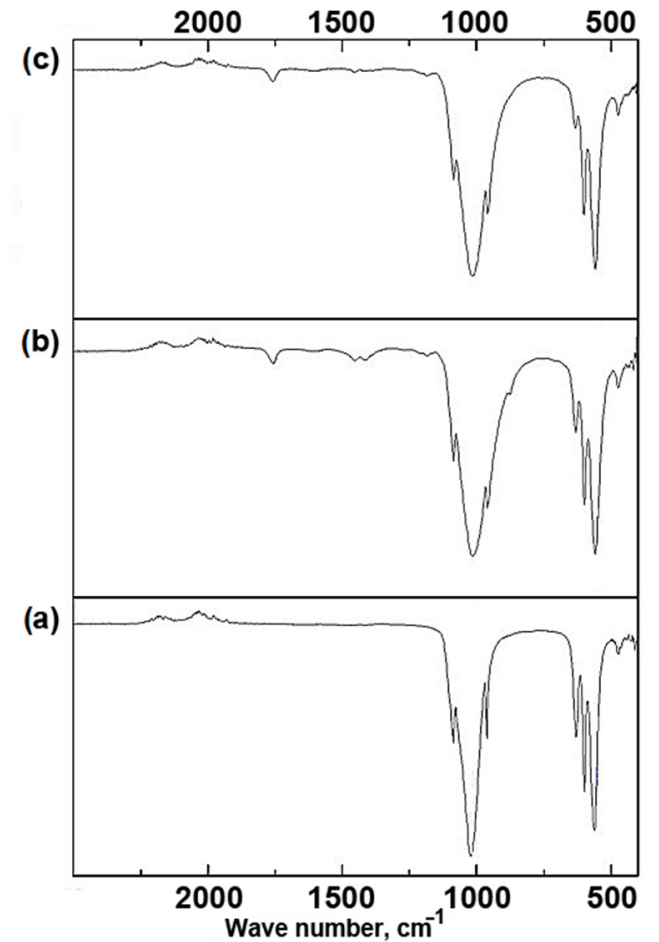

Figure 3. IR spectra of (a) $\mathrm{Zn}_{\mathrm{x}} \mathrm{HA}(\mathrm{x}=0.1)$, (b) Zn $\mathrm{n}_{\mathrm{x}} \mathrm{HA}-\mathrm{PLGA}(\mathrm{x}=0.1)$, (c) $\mathrm{Zn} \mathrm{n}_{\mathrm{x}} \mathrm{HA}-\mathrm{PLGA}$ $(\mathrm{x}=0.5)$ samples.

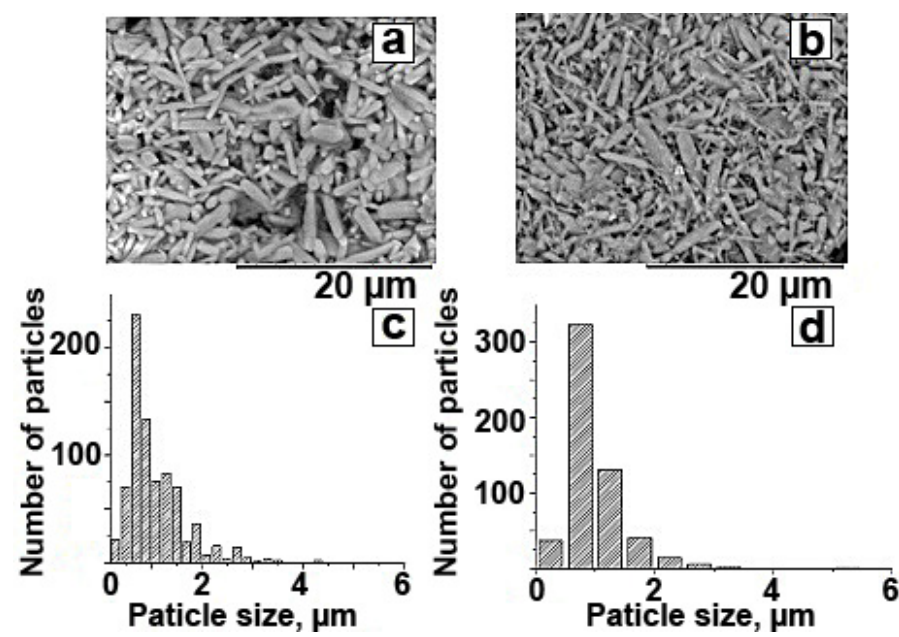

Figure 4. SEM images of composites: (a) Zn ${ }_{x} H A-P L G A(x=0.1),(b) Z n_{x} H A-P L G A(x=0.5)$ and the quantitative distribution of particles over the surface: (c) Zn $n_{x} H A-P L G A(x=0.1)$, (d) Zn $n_{x} H A-P L G A$ $(x=0.5)$.

Table 2. Elemental composition of $\mathrm{Zn}_{\mathrm{x}} \mathrm{HA}$ powders.

\begin{tabular}{|c|c|c|c|c|c|c|}
\hline \multirow{2}{*}{ Sample } & \multicolumn{5}{|c|}{ Element Content (at.\%) } & \multirow{2}{*}{$\frac{\mathrm{Ca}+\mathrm{Zn}}{\mathrm{P}}$} \\
\hline & $\mathrm{O}$ & $\mathrm{Ca}$ & $\mathbf{P}$ & $\mathrm{Zn}$ & $\mathrm{C}$ & \\
\hline $\mathrm{Zn}_{\mathrm{x}} \mathrm{HA}-\mathrm{PLGA}(\mathrm{x}=0.1)$ & 57.5 & 12.8 & 7.3 & 0.2 & 22.2 & 1.7 \\
\hline $\mathrm{Zn}_{\mathrm{x}} \mathrm{HA}-\mathrm{PLGA}(\mathrm{x}=0.5)$ & 56.3 & 15.9 & 9.6 & 1.3 & 16.8 & 1.8 \\
\hline
\end{tabular}

\subsection{Investigation of the Solubility of Composites}

The solubility of HA in the composition of composites significantly decreases relative to a pure framework, probably due to the fact that the diffusion of calcium ions through 
the polymer layer is hindered; the solubility (S) of pure frameworks is much higher in this case (Figure 5a).
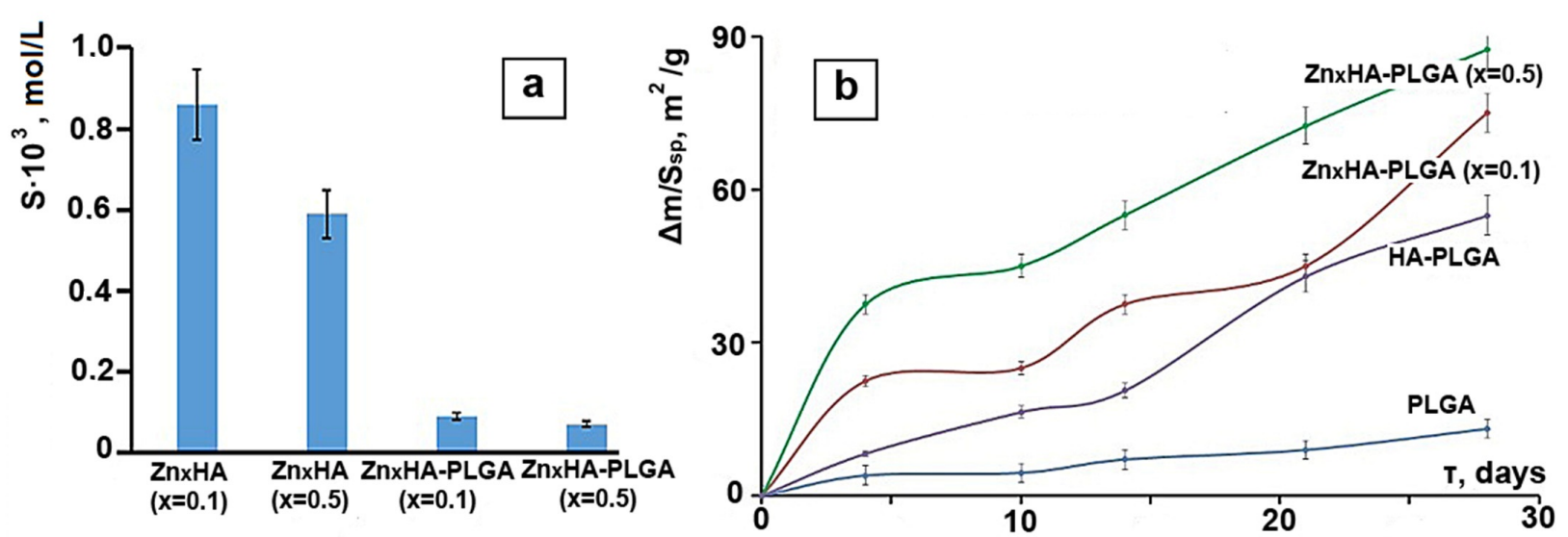

Figure 5. (a) Solubility (S) of HA in the composition of $\mathrm{Zn}_{\mathrm{x}} \mathrm{HA}-\mathrm{PLGA}$ composites; (b) weight loss $(\Delta \mathrm{m})$ of materials reduced to unit-specific surface area (Ssp) when kept in phosphate buffer $\mathrm{pH}=7.4$.

Evaluation of the rate of weight loss of materials reduced to specific surface area shows that the addition of zinc significantly affects the solubility of materials in comparison with a material based on pure hydroxyapatite (Figure $5 b$ ). It can be concluded that the addition of zinc significantly affects the solubility of materials [31]. This is probably due to the fact that zinc, being embedded in the crystal lattice, creates a large number of defects, which subsequently leads to the acceleration of its destruction. It can accelerate the resorption of the hydroxyapatite framework and maintain a high concentration of zinc at the implant site, which will provide antibacterial properties throughout the restoration of the damaged area.

\subsection{Assessment of the Effect of Materials on the Viability of Cells of the Immune System}

The viability test showed (Figure 6) that human macrophages incubated on composite samples are generally comparable to the control sample (cells incubated without a sample). Cell viability on the $\mathrm{Zn}_{\mathrm{x}} \mathrm{HA}-\mathrm{PLGA}\left(\mathrm{x}=0.5\right.$ ) composite is slightly higher than that of $\mathrm{Zn}_{\mathrm{x}} \mathrm{HA}$ PLGA $(x=0.1)$. It can also be observed that some donors have an individual reaction to the material—donor 1 showed a lower viability relative to all samples. When comparing the behavior of materials in the presence of macrophages with materials of another type where dispersed HA is enclosed in a polymer matrix [35], we can observe that the viability of macrophages decreases with an increase in the concentration of hydroxyapatite. Despite the fact that in our materials HA has a much higher concentration, doping with zinc can significantly improve the viability of macrophages when they are incubated together with the materials.

\subsection{Evaluation of the Antibacterial Activity of Samples}

Samples of the composition $\mathrm{Zn}_{\mathrm{x}} \mathrm{HA}(\mathrm{x}=0.1)$ had a weak suppressive effect on the number of Staphylococcus aureus (Table 3). The number of bacteria in the liquid medium with this sample is slightly less than in the control sample. The $\mathrm{Zn}_{\mathrm{x}} \mathrm{HA}(\mathrm{x}=0.5)$ sample showed antibacterial activity, significantly reducing the number of Staphylococcus aureus compared with the control sample. This was statistically confirmed $(p<0.001)$. Samples $\mathrm{Zn}_{x} \mathrm{HA}-$ PLGA $(x=0.1)$ and $Z n_{x}$ HA-PLGA $(x=0.5)$ showed slightly less antibacterial activity than samples $\mathrm{Zn}_{\mathrm{x}} \mathrm{HA}$. This may be due to the lower yield of zinc ions from these samples due to the enveloping of the hydroxyapatite particles by the copolymer. Comparison samples (HA and PLGA) did not show antibacterial activity $(p>0.05)$. No extraneous microflora was found on the nutrient medium: all colonies were assigned to the studied text-object by morphological characteristics. Prosolov et al. [36] found that with an increase in the solubility of the material based on zinc-doped $\mathrm{Ca} / \mathrm{P}$, as in our case, came the suppression 
of Staphylococcus aureus, although in our case the polymer film somewhat hindered the complete release of zinc ions.

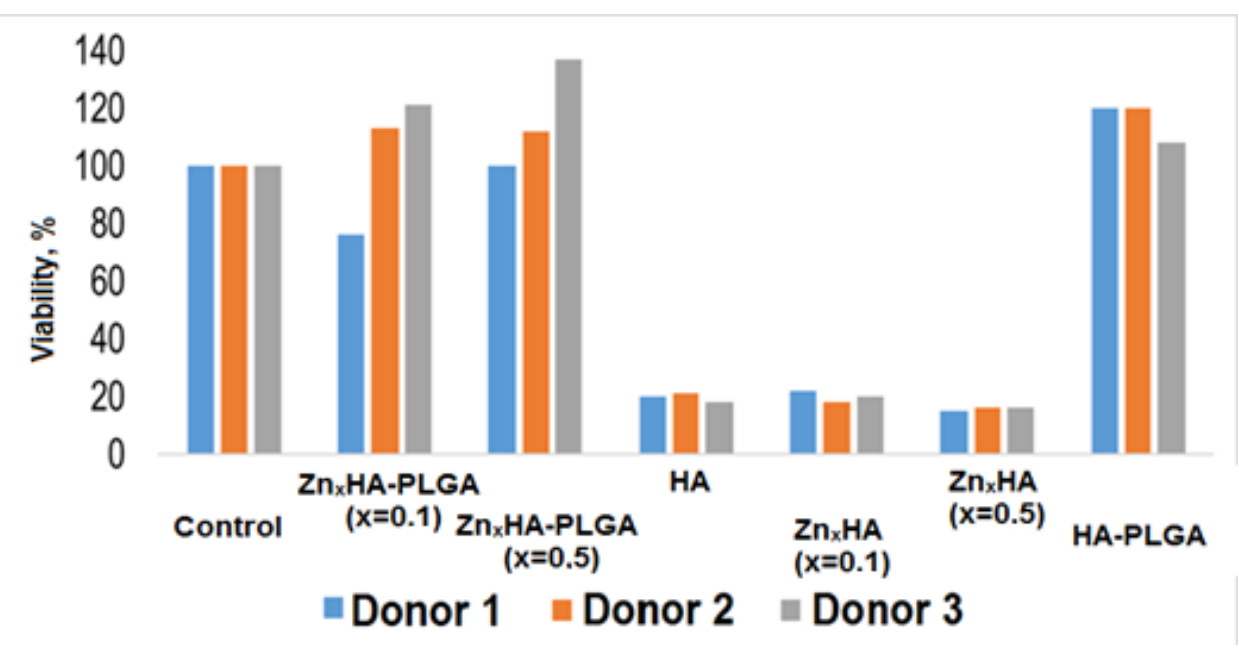

Figure 6. Viability of human macrophages in the presence of $\mathrm{Zn}_{\mathrm{x}} \mathrm{HA}-\mathrm{PLGA}$ composites.

Table 3. Influence of different accessions on the abundance of E. Coli and S. aureus.

\begin{tabular}{ccc}
\hline Samples & Number . coli, CFU/mL & Number S. aureus, CFU/mL \\
\hline Control & $(1.19 \pm 0.0407) \times 10^{8}$ & $(1.74 \pm 0.092) \times 10^{8}$ \\
HA & $(0.847 \pm 0.118) \times 10^{8}$ & $(1.73 \pm 0.060) \times 10^{8}$ \\
PLGA & $(1.14 \pm 0.118) \times 10^{8}$ & $(1.75 \pm 0.114) \times 10^{8}$ \\
Zn $\mathrm{n}$ H $(x=0.1)$ & $(0.340 \pm 0.030) \times 10^{8}$ & $(1.32 \pm 0.053) \times 10^{8}$ \\
Zn $\mathrm{x}$ HA $(x=0.5)$ & $(0.215 \pm 0.028) \times 10^{8}$ & $(0.247 \pm 0.040) \times 10^{8}$ \\
$\mathrm{Zn}_{\mathrm{x}} \mathrm{HA}-\mathrm{PLGA}(\mathrm{x}=0.1)$ & $(1.26 \pm 0.100) \times 10^{8}$ & $(1.07 \pm 0.077) \times 10^{8}$ \\
$\mathrm{Zn}_{\mathrm{x}} \mathrm{HA}-\mathrm{PLGA}(\mathrm{x}=0.5)$ & $(1.06 \pm 0.0655) \times 10^{8}$ & $(0.367 \pm 0.042) \times 10^{8}$ \\
\hline
\end{tabular}

The study of the antibacterial activity of samples $\mathrm{Zn}_{\mathrm{x}} \mathrm{HA}(\mathrm{x}=0.1)$ and $\mathrm{Zn}_{\mathrm{x}} \mathrm{HA}-\mathrm{PLGA}$ $(x=0.5)$ showed antibacterial activity, significantly reducing the number of E. coli in comparison with the control sample $(p<0.001)$ (Table 3$)$. At the same time, samples on E. coli showed that the composites are less active against gram-negative microflora than against gram-positive. $\mathrm{Zn}_{\mathrm{x}} \mathrm{HA}$-PLGA $(\mathrm{x}=0.1)$ and $\mathrm{Zn}_{\mathrm{x}} \mathrm{HA}-\mathrm{PLGA}(\mathrm{x}=0.5)$ did not show antibacterial activity $(p>0.05)$. It can be assumed that this is due to the specific features of the $\mathrm{Zn}_{\mathrm{x}} \mathrm{HA}$-PLGA samples. Presumably, particles of $\mathrm{Zn}_{\mathrm{x}} \mathrm{HA}$-PLGA composites form large aggregates with lower bioavailability than $\mathrm{Zn}_{\mathrm{x}} \mathrm{HA}$ particles without copolymer. The lower activity of the composites against E. coli may be associated with the greater overall resistance of gram-negative bacteria.

\section{Conclusions}

Based on the results of experimental and calculated data obtained by physicochemical and biological methods, the following conclusions were drawn. Samples of zinc-modified hydroxyapatite $\mathrm{Zn}_{\mathrm{x}} \mathrm{HA}$ with different zinc content $(\mathrm{x}=0.1$ and $0.5 \mathrm{~mol})$ were synthesized by the liquid-phase method. It was found that the obtained samples are represented by the phase of hydroxyapatite $\mathrm{Ca}_{10}\left(\mathrm{PO}_{4}\right)_{6}(\mathrm{OH})_{2}$ hex, with zinc included in the structure of hydroxyapatite. Composite materials based on zinc-modified hydroxyapatite $(\mathrm{Zn}=0.1 ; 0.5 \mathrm{~mol})$ and a copolymer of lactide and glycolide with a ratio of HA/PLGA $=93 / 7 \mathrm{wt} . \%$ with a volume porosity of $16 \mathrm{vol} . \%$ were obtained. The uniform distribution of zinc and carbon over the surface of composite samples $\mathrm{Zn}_{\mathrm{x}} \mathrm{HA}-\mathrm{PLGA}(\mathrm{x}=0.1)$ and $\mathrm{Zn}_{\mathrm{x}} \mathrm{HA}-\mathrm{PLGA}(\mathrm{x}=0.5)$ was established. It was shown that the size of acicular particles of hydroxyapatite of the obtained material for $\mathrm{Zn}_{\mathrm{x}} \mathrm{HA}$ ( $\mathrm{x}=0.1$ ) is $1.2 \pm 0.1 \mu \mathrm{m}$, and for $\mathrm{Zn}_{0.5} \mathrm{HA}$ it is $0.9 \pm 0.1 \mu \mathrm{m}$. The elemental composition of the synthesized $\mathrm{Zn}_{\mathrm{x}} \mathrm{HA}$ powders according to the results 
of XRD analysis show that the atomic ratio of elements $(\mathrm{Ca}+\mathrm{Zn}) / \mathrm{P}$ is 1.7 for $\mathrm{Zn}_{\mathrm{x}} \mathrm{HA}$ $(\mathrm{x}=0.1)$ and 1.8 for $\mathrm{Zn} \mathrm{HA}(\mathrm{x}=0.5)$, which corresponds to the ratio of $\mathrm{Ca} / \mathrm{P}$ elements for bone tissue (1.4-2.0). The process of dissolution of hydroxyapatite in physiological saline was investigated. It was found that an increase in the content of zinc in hydroxyapatite leads to a decrease in solubility in physiological solution compared to unmodified HA. The solubility of composites decreases which is associated with the difficulty of diffusion of calcium ions through the polymer layer. The cytotoxicity of the obtained composite materials was studied. It was found that the viability of macrophages incubated on the $\mathrm{Zn}$ HA-PLGA $(x=0.5)$ composite is higher than on $\mathrm{Zn}_{\mathrm{x}} \mathrm{HA}-\mathrm{PLGA}(\mathrm{x}=0.1)$. It was shown that the samples obtained in this work based on $\mathrm{Zn}_{\mathrm{x}} \mathrm{HA}$ and PLGA possess antibacterial properties against gram-positive microflora.

Author Contributions: Conceptualization, I.K. and D.L.; methodology, I.K.; formal analysis, A.G. and D.L.; investigation, A.G. and D.F.; writing-original draft preparation, A.G. and D.L.; writingreview and editing, I.K. and D.L. All authors have read and agreed to the published version of the manuscript.

Funding: This work was supported by the Ministry of Science and Higher Education (project number 0721-2020-0037).

Institutional Review Board Statement: The study was conducted according to the guidelines of the Declaration of Helsinki and approved by the Ethics Committee of Tomsk State University (Protocol of the meeting of NR TSU Bioethics Commission, Protocol No 1 from 3 February 2017, extract from Protocol No 1).

Informed Consent Statement: Not applicable.

Data Availability Statement: The datasets used and/or analyzed during the current study are available from the corresponding author on reasonable request.

Conflicts of Interest: The authors declare no conflict of interest.

\section{References}

1. Suchanek, W.; Yoshimura, M. Processing and properties of hydroxyapatite-based biomaterials for use as hard tissue replacement implants. J. Mater. Res. 1998, 13, 94-117. [CrossRef]

2. Bilezikian, J.P.; Raisz, L.G.; Rodan, G.A. Principles of Bone Biology, 4th ed.; Bilezikian, J.P., Raisz, L.G., Rodan, G.A., Eds.; Academic Press: San Diego, CA, USA, 2002; Volume 1-2.

3. Von Euw, S.; Wang, Y.; Laurent, G.; Drouet, C.; Babonneau, F.; Nassif, N.; Azaïs, T. Bone mineral: New insights into its chemical composition. Sci. Rep. 2019, 9, 8456. [CrossRef]

4. LeGeros, R.Z.; Lin, S.; Rohanizadeh, R.; Mijares, D.; LeGeros, J.P. Biphasic calcium phosphate bioceramics: Preparation, properties and applications. J. Mater. Sci. Mater. Med. 2003, 14, 201-209. [CrossRef]

5. Catauro, M.; Bollino, F.; Papale, F. Investigation on bioactivity, biocompatibility, thermal behavior and antibacterial properties of calcium silicate glass coatings containing Ag. J. Non-Cryst. Sol. 2015, 422, 16-22. [CrossRef]

6. Lim, P.N.; Chang, L.; Thian, E.S. Development of nanosized silver-substituted apatite for biomedical applications: A review. Nanomed. Nanotechnol. Biol. Med. 2015, 11, 1331-1344. [CrossRef]

7. Singh, B.; Kumar, A.; Kumar, D.S. In vitro biocompatibility and antimicrobial activity of wet chemically prepared $\mathrm{Ca}_{10-\mathrm{x}} \mathrm{Ag}_{\mathrm{x}}\left(\mathrm{PO}_{4}\right)_{6}(\mathrm{OH})_{2}(0.0 \leq \mathrm{x} \leq 0.5)$ hydroxyapatites. Mater. Sci. Eng. 2011, 31, 1320-1329. [CrossRef]

8. Barinov, S.M.; Komlev, V.S. Bioceramics in Medicine; Nauka: Moscow, Russia, 2005; 284p.

9. Cox, S.C.; Jamshidi, P.; Grover, L.M.; Mallick, K.K. Preparation and characterisation of nanophase Sr, Mg, and Zn substituted hydroxyapatite by aqueous precipitation. Mater. Sci. Eng. C Mater. Biol. Appl. 2014, 35, 106-114. [CrossRef] [PubMed]

10. DeJong, E.S.; DeBerardino, T.M.; Brooks, D.E.; Nelson, B.J.; Campbell, A.A.; Bottoni, C.R.; Pusateri, A.E.; Walton, R.S.; Guymon, C.H.; McManus, A.T. Antimicrobial efficacy of external fixator pins coated with a lipid stabilized hydroxyapatite/chlorhexidine complex to prevent pin tract infection in a goat model. J. Trauma. 2001, 50, 1008-1014. [CrossRef]

11. Ciobanu, C.S.; Iconaru, S.L.; Chifiriuc, M.C.; Costescu, A.; Le Coustumer, P.; Predoi, D. Synthesis and antimicrobial activity of silver-doped hydroxyapatite nanoparticles. Biomed. Res. Int. 2013, 2013, 916218. [CrossRef]

12. Plum, L.M.; Rink, L.; Haase, H. The essential toxin: Impact of zinc on human health. Int. J. Environ. Res. Public Health 2010, 7, 1342-1365. [CrossRef]

13. Wastney, M.E.; Aamodt, R.L.; Rumble, W.F.; Henkin, R.I. Kinetic analysis of zinc metabolism and its regulation in normal humans. Am. J. Physiol. 1986, 251, R398-R408. [CrossRef] 
14. Fiske, D.N.; McCoy, H.E.; Kitchens, C.S. Zinc-induced sideroblastic anemia: Report of a case, review of the literature, and description of the hematologic syndrome. Am. J. Hematol. 1994, 46, 147-150. [CrossRef]

15. Prohaska, J.R. Biochemical changes in copper deficiency. J. Nutr. Biochem. 1990, 1, 452-461. [CrossRef]

16. Sandstead, H.H. Requirements and toxicity of essential trace elements, illustrated by zinc and copper. Am. J. Clin. Nutr. 1995, 61, 621S-624S. [CrossRef]

17. Beyersmann, D.; Hartwig, A. Carcinogenic metal compounds: Recent insight into molecular and cellular mechanisms. Arch. Toxicol. 2008, 82, 493-512. [CrossRef]

18. Honscheid, A.; Rink, L.; Haase, H. T-lymphocytes: A target for stimulatory and inhibitory effects of zinc ions. Endocr. Metab. Immune Disord. Drug Targets 2009, 9, 132-144. [CrossRef]

19. Rink, L.; Gabriel, P. Zinc and the immune system. Proc. Nutr. Soc. 2000, 59, 541-552. [CrossRef]

20. Delafuente, J.C. Nutrients and immune responses. Rheum. Dis. Clin. N. Am. 1991, 17, 203-212. [CrossRef]

21. Fraker, P.J.; DePasquale-Jardieu, P.; Zwickl, C.M.; Luecke, R.W. Regeneration of T-cell helper function in zinc-deficient adult mice. Proc. Natl. Acad. Sci. USA 1978, 75, 5660-5664. [CrossRef]

22. Haase, H.; Rink, L. Functional significance of zinc-related signaling pathways in immune cells. Annu. Rev. Nutr. 2009, 29, 133-152. [CrossRef]

23. Cummings, J.E.; Kovacic, J.P. The ubiquitous role of zinc in health and disease. J. Vet. Emerg. Crit. Care 2009, 19, 215-240. [CrossRef]

24. Formigari, A.; Irato, P.; Santon, A. Zinc, antioxidant systems and metallothionein in metal mediated-apoptosis: Biochemical and cytochemical aspects. Comp. Biochem. Physiol. Part C 2007, 146, 443-459. [CrossRef]

25. Haase, H.; Watjen, W.; Beyersmann, D. Zinc induces apoptosis that can be suppressed by lanthanum in C6 rat glioma cells. Biol. Chem. 2001, 382, 1227-1234. [CrossRef]

26. Truong-Tran, A.Q.; Carter, J.; Ruffin, R.E.; Zalewski, P.D. The role of zinc in caspase activation and apoptotic cell death. Biometals 2001, 14, 315-330. [CrossRef]

27. Lytkina, D.; Gutsalova, A.; Fedorishin, D.; Korotchenko, N.; Akhmedzhanov, R.; Kozik, V.; Kurzina, I. Synthesis and properties of zinc-modified hydroxyapatite. J. Funct. Biomater. 2020, 11, 10. [CrossRef]

28. Botvin, V.; Pozdniakov, M.; Filimoshkin, A. Intermolecular "zipper" type depolymerization of oligomeric molecules of lactic and glycolic acids prepacked as paired associates. Polym. Degrad. Stab. 2017, 146, 126-131. [CrossRef]

29. Lytkina, D.; Heinrich, L.; Churina, E.; Kurzina, I. Biocompatible composite materials based on porous hydroxyapatite ceramics and copolymer of lactide and glycolide. Materials 2021, 14, 2168. [CrossRef]

30. Lurie, Y.Y. Handbook of Analytical Chemistry, 6th ed.; Khimiya: Moscow, Russia, 1989; 448p.

31. Resslera, A.; Žužića, A.; Ivaniševića, I.; Kambojb, N.; Ivanković, H. Ionic substituted hydroxyapatite for bone regeneration applications: A review. Open Ceram 2021, 6, 100122. [CrossRef]

32. Smith, A. Applied IR Spectroscopy; Mir Publishers: Moscow, Russia, 1982; 382p.

33. Masuyama, R.; Nakaya, Y.; Katsumata, S.; Kajita, Y.; Uehara, M.; Tanaka, S.; Sakai, A.; Kato, S.; Nakamura, T.; Suzuki, K. Dietary calcium and phosphorus ratio regulates bone mineralization and turnover in vitamin $\mathrm{D}$ receptor knockout mice by affecting intestinal calcium and phosphorus absorption. J. Bone Miner. Res. 2003, 18, 1217-1226. [CrossRef]

34. Kourkoumelis, N.; Tzaphlidou, M. Spectroscopic assessment of normal cortical bone: Differences in relation to bone site and sex. Sci. World J. 2010, 10, 402-412. [CrossRef]

35. Kurzina, I.; Churina, Y.; Shapovalova, Y.; Syusyukina, V.; Kzhyshkowska, J. Immunomodulatory properties of composite materials based on polylactide and hydroxyapatite. Bioceram. Dev. Appl. 2018, 8, 109. [CrossRef]

36. Prosolov, K.A.; Mitrichenko, D.V.; Prosolov, A.B.; Nikolaeva, O.O.; Lastovka, V.V.; Belyavskaya, O.A.; Chebodaeva, V.A.; Glukhov, I.A.; Litvinova, L.S.; Shupletsova, V.V.; et al. Zn-doped CaP-based coatings on Ti-6Al-4V and Ti-6Al-7Nb alloys prepared by magnetron sputtering: Controllable biodegradation, bacteriostatic, and osteogenic activities. Coatings 2021, 11, 809. [CrossRef] 